\title{
"Policyjny Dom Zdrowia" (P.D.Z., Policemen's Health Center) as the example of a big sanatorium facility in the valley of the Prut River in the Hutsul region
}

\author{
Jacek Czubiński \\ jacek.czubinski@wp.pl \\ Institute of the History of Architecture and Monument Conservation, Cracow University of Technology
}

\begin{abstract}
The article presents the building of State Police Sanatorium in Tatarów in the context of other big buildings with timber structure erected ca. 1930 in the valley of the Prut River in the Hutsul region. Several facilities of this kind were constructed there at that time, with total capacity of over 80 visitors at a time. "Znicz" Railwayman Family Association's guesthouse was commissioned in Tatarów. Tax Officials Society constructed the "Skarbówka" guesthouse in Worochta. In Jaremcze-Jamna, "Gorgany" Health House of the Association of Tax Control Officials of the Republic of Poland began its operations. In mid1930s, guesthouse for the Association of Ukrainian Teachers was designed in the same town.
\end{abstract}

Keywords: spa architecture, Hutsul region, State Police Sanatorium, Tatarów

\section{Introduction}

The end of the First World War is directly connected with the restoration of state and establishing new reality in all fields of social activity. In 1922, the parliament adopted the act on sanatoria and spa centers, thus providing legal framework for the organization and activity of local holiday resorts [Dziennik 1922]. At that time they were categorized and divided into spa centers, climate stations as well as seaside resorts. The category of public utility sanatorium resort emerged. The towns had the possibility to acquire such status by means of the ordinance of the Council of Ministers upon the order of the Minister of Public Health. The act provided such centers with the privilege of state support. In 1928, basing on the ordinance of the President of the Republic of Poland as of 22.03.1928 [Dziennik 1928] amending the parliamentary act on sanatorium centers as of 1922, Jaremcze and Worochta, together with eleven other sanatorium centers, received the status of public utility sanatorium centers. This fact contributed to the development of neighboring towns and villages, including Tatarów. Several new treatment facilities were constructed there in the 1920s. Some of them are going to be presented below ${ }^{1}$.

Numerous trade associations and societies used to emerge in the interwar period, connected with different state institutions or social organizations. Healthcare constituted an important element of their activity. Their members had the opportunity to receive treatment or stay for holidays on preferential conditions in sanatoria and guesthouses owned by such associations. The construction of new buildings was initiated particularly frequently in the second half of the 1920s. The investments were managed centrally or represented a local

1 For many years, the author has been conducting the research on spa architecture in the towns and villages situated in the valley of the upper Prut River in the Hutsul region at the Institute of the History of Architecture and Monument Conservation of Cracow University of Technology, together with the staff from the Institute of Touristic Architecture of the Ivano-Frankivsk National Technical University of Oil and Gas. 
character. In the Hutsul region, where buildings with relatively limited capacity prevailed [Czubiński 2008], few big sanatoria or guesthouses were established, so frequently encountered in Western Carpathians. The oldest big sanatorium, erected already before WW1, was Dr. Michalik's facility in Worochta. It was constructed in mid-1930s by the State Sickness Fund. In the same town, the Association of Jewish Academics constructed in the late 1920 s a tuberculosis sanatorium. Around 1930, several other facilities began their operations, with the capacity of over 80 visitors at a time. The sanatorium of Policemen's Health Center Association together with "Znicz" Railwayman Family Association's guesthouse were commissioned in Tatarów. Tax Officials Society constructed the "Skarbówka" guesthouse in Worochta. In Jaremcze-Jamna, "Gorgany" Health House of the Association of Tax Control Officials of the Republic of Poland began its operations. In mid-1930s, guesthouse for the Association of Ukrainian Teachers was designed in the same town.

The purpose of the article is to present State Police Sanatorium in Tatarów in the context of other big buildings with timber structure. It is necessary to emphasize that the only building representing this group until current times is the said police sanatorium.

\section{Policemen's Health Center in Tatarów}

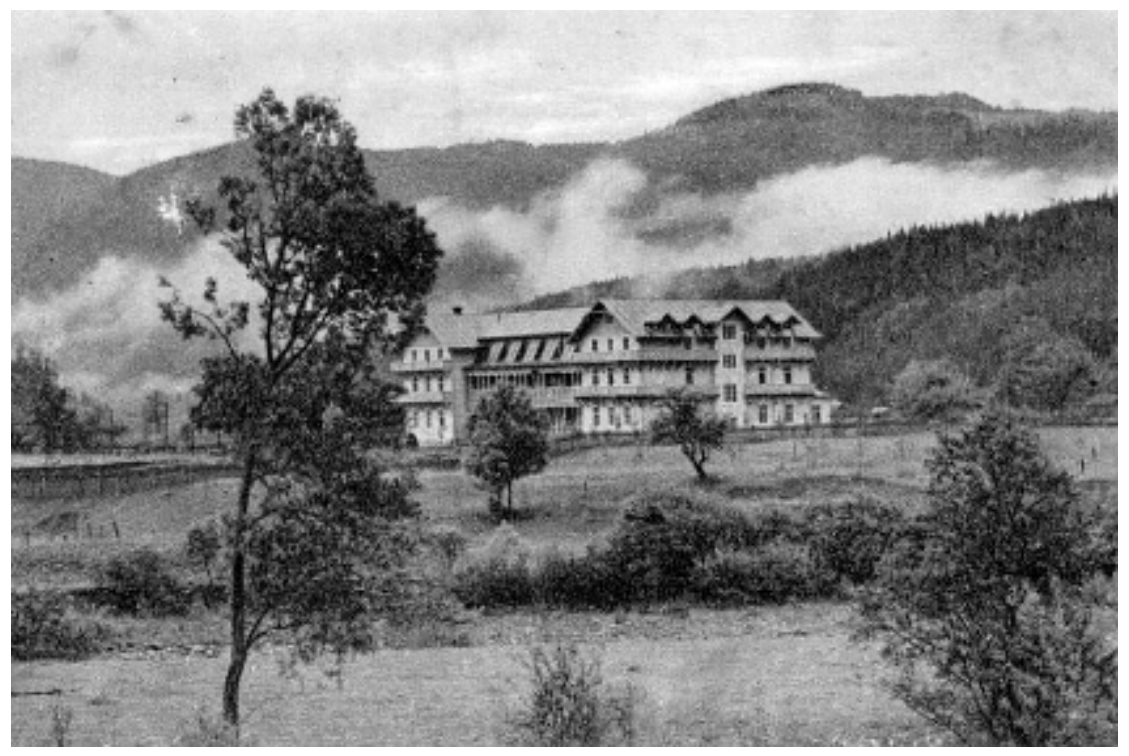

Fig. 1. Tatarów, Policemen's Health Center, 1930s Postcard from author's own collection. Tatarów, Policyjny Dom Zdrowia, lata 30. XX. w. Karta pocztowa w zbiorach autora.

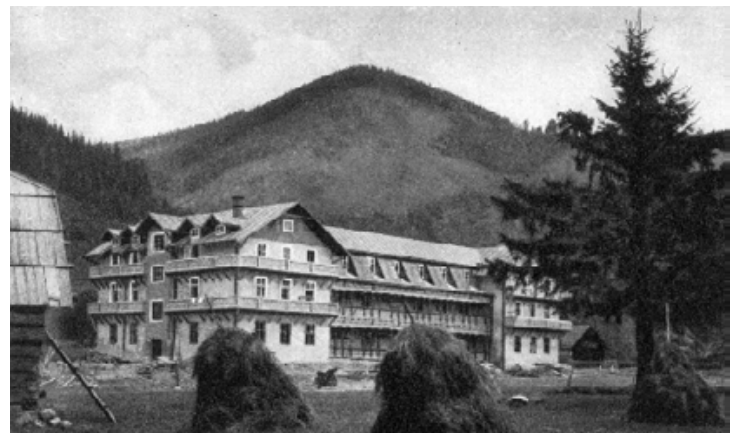

Fig. 2. Tatarów, Policemen's Health Center, ca. 1930 Postcard from author's own collection.

Tatarów, Policyjny Dom Zdrowia, około 1930 r. Karta pocztowa w zbiorach autora.

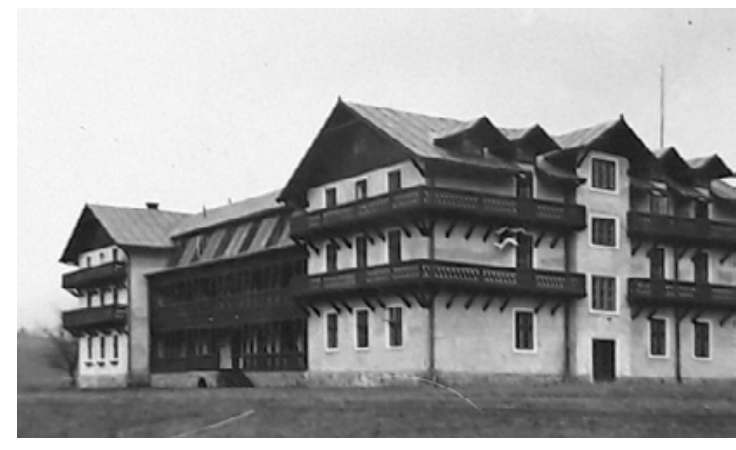

Fig. 3. Tatarów, Policemen's Health Center, ca. 1930 Archival photo [AAD-ZZS, sign. 112].

Tatarów, Policyjny Dom Zdrowia, około 1930 r. Fotografia archiwalna [AAD-ZZS, sygn. 112] 
The sanatorium is situated in the Northern part of the town of Tatarów, in a vast park, on flat land area over the Prut River escarpment (Photo 1-4). This is a multi-level wooden building, covered with a gable roof and based on the elongated $\mathrm{H}$-shaped rectangular plan. Within the structure of the building, in its Southern and Northern façades, three-level side avant-corpses can be found. They are covered with gable roofs including dormers. Mansard roof is present over the two-level central section, with deep windows situated in its lower parts. Balconies were designed on the first and second level of the building. Entrances were located on the Western and Eastern façade. The building has the ground floor and the first floor in its central part, with additional usable level in the attic. At the level of the first floor within the Southern and Northern façade, continuous balcony can be found, with pillars supporting roof eaves, considerable in size. Railings and brackets for the eaves and balconies are ornamented with regional carpentry patterns. The building was initially plastered in white. The plaster was removed after the war and its walls were covered with vertically arranged boards. Two-level residential and utility wing was added to the building after the war from the North, together with the dining room in the section consisting only of the ground floor. There are numerous objects erected in different periods on the area surrounding the building. Some of them were constructed before 1939, as it was for example the case with the summer dining room or residential building with classicizing portico. The complex has been preserved until today in a relatively good condition and since 1990s it serves the function of the sanatorium of the Ukrainian Ministry of Internal Affairs (Photo 5).

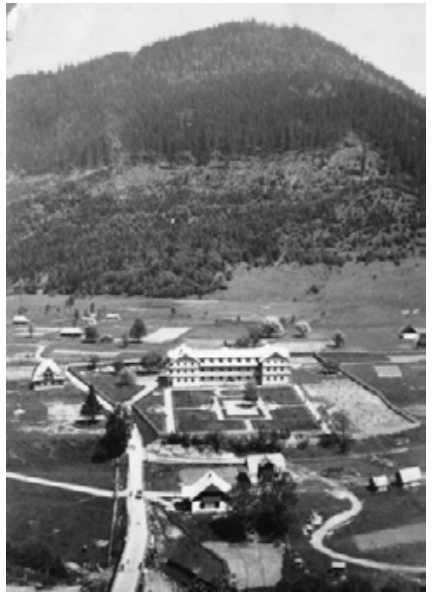

Fig. 4. Tatarów. Policemen's Health Center, 1930s Archival photo from author's own collection.

Tatarów. Policyjny Dom Zdrowia, lata 30. XX. w. Fotografia archiwalna w zbiorach autora.

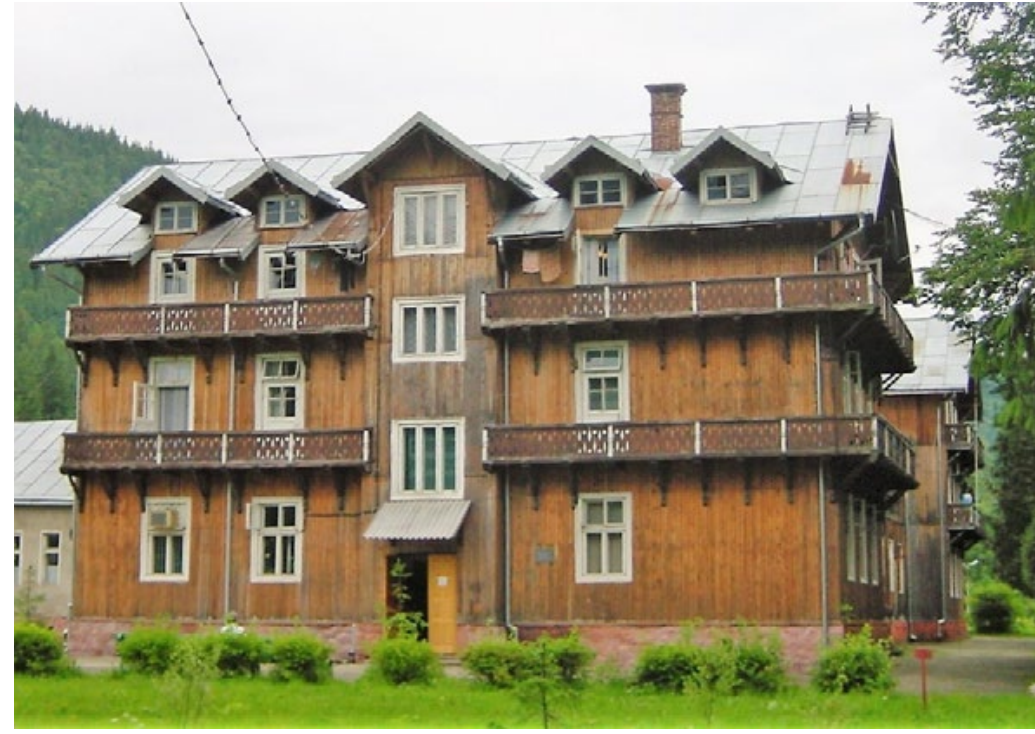

Fig. 5. Tatarów. Policemen's Health Center, 2008. Photo: Jacek Czubiński. Tatarów. Policyjny Dom Zdrowia, 2008 r. Fot.: Jacek Czubiński.

In the interwar period, full name of the facility was worded as follows: The Sanatorium of Policemen's Health Center Association in Tatarów. The association was established on June $28^{\text {th }} 1924$, during the First General Meeting of the delegates of District Police Headquarters [Gazeta 1924]. Its statute was approved by the Minister of Internal Affairs on 23.02.1924 [Stowarzyszenie, p. 3] and amended in 1926 [Rocznik, p.59]. Main function of the association's activity was to: "provide the policemen with aid through establishing and maintaining health centers, houses for convalescents and relaxation facilities, sanatoria and similar establishments where a sick policeman could find appropriate care and efficient support" [Stowarzyszenie, p. 4]. The association used treatment centers in: Busko Zdrój, Druskienniki, Otwock, Tatarów and Zakopane. It also owned property and plots for construction purposes among others in: Bliżyn, Duboja, Ponary, Toruń, Warsaw, Wejherowo and Zaklików. The construction of sanatoria in Orłowo, Muszyna and Wejherowo was planned [Stowarzyszenie, p. 4-6]. Buildings were also leased or rooms rented in guesthouses situated in such cities and towns as Częstochowa, Krynica, Rabka or Truskawiec [AAD-KGPP, 1030]. This is how the property of the Association was presented in 1938: "At the beginning of the fourteenth year of its functioning, the Association holds the property estimated realistically 
at 1.5 million zlotys, consisting of one hospital, 3 sanatoria, 1 guesthouse, 2 commercial houses and several plots of land. About 3000 visitors enjoyed their stay in the Association's facilities last year" ${ }^{2}$.

The construction of the sanatorium in Tatarów was initiated in 1925, when "The police of the Stanistawów voivodeship organized in a self-help unit purchased the parcel in Tatarów and began the construction of a summer facility there. The started construction collapsed as a result of the errors made, and insufficient funds forced the Stanisławów self-help unit to resign from its reconstruction and the started project was handed over to P.D.Z. and they became P.D.Z. members themselves ${ }^{\prime \prime 3}$. The building began to serve a new function - from the summer house it was transformed into a tuberculosis sanatorium ${ }^{4}$. Finishing works began in March 1928. After numerous difficulties caused by unreliable contractors, first 80 visitors were received on May $1^{\text {st }} 1929$. The facility was officially commissioned on 15.01 .1930 [Stowarzyszenie, p. 9]. On August $28^{\text {th }} 1930$, the sanatorium was provided by the Ministry of Health with the status of sanatorium for treating lung diseases, including tuberculosis ${ }^{5}$. After it began its operations, there were still the works connected with arranging the surroundings of the building to be performed, together with purchasing the missing equipment. The construction of a separate administrative building was also planned, including the flats for doctors and other staff, as well as stables, a cowshed and a pigsty together with an ice storing facility. Further works were performed in the years to come. The building was protected against flooding with the water coming down from the mountains thanks to the drainage ditches $\mathrm{dug}^{6}$. In order to ensure the access to the facility, the bridge over the Prut River was constructed in cooperation with Railway Sanatorium in Tatarów ${ }^{7}$. In 1933 final borders of the plot were determined and about 300 trees were planted within the fenced area, thus giving it the character of a park. 8

As a result, a modern facility was constructed in which "the majority of rooms have the windows facing South and South-East, with only a few of them facing West. Roofed verandas can be found on the ground floor and the first floor, making it possible for the sick to relax outside also when it's raining. The entire building has electric lighting, central heating and the majority of rooms have running cold and hot water, each level has its toilets and bathrooms connected to the sewage network. The sanatorium has its doctor's study, a big dining hall (with a radio loudspeaker and a gramophone), a common room and its own library. It is equipped with an X-ray machine for scans, quartz lamps, mobile laboratory for the analysis of sputum, urine, stomach content etc. as well as with a first aid kit containing ready-made drugs. What is more, water and steam sterilizer for dishes is located by the exemplarily equipped kitchen, together with a sterilizer for spittoons in a separate room. The linen is washed in a mechanical laundry" [Stowarzyszenie 1935, p. 38].

In total there were 66 rooms in the building, including 41 serving residential purposes and having the capacity of about 85 guests $^{9} .225$ patients were received in the year 1930. In the following years this number oscillated from 332 to 444 persons (in $1931-388,1932-296,1933-405,1934-444,1935-332$ ) ${ }^{10}$. The analysis of this data shows that the capacity of the sanatorium was used in maximum 50 percent. To compare: in the facility in Zakopane, this ratio amounted from 53 to 72\%, in Otwock $75-95 \%$, in Busko over 100\% and in Druskienniki between 20 and 35\%.

In 1930, the attendance would reach about 65 visitors in the summer period. In the autumn hardly anybody visited the facility, as a result of which the Board of the Association was considering, a resolution had even been adopted in this field and then cancelled, to close the facility and dismiss its staff by February $28^{\text {th }} 1931^{11}$. In the winter of 1931 there were on average 55 visitors a month in the sanatorium, 74 from April to September and 20 patients in the autumn. Summer and winter camps for policemen's children were also organized in the building. For example in 1933, after the break lasting from November $1^{\text {st }}$ to December $19^{\text {th }}$, a group consisting 
of 100 state policemen's children was received. It was finally decided for all-year operations of the facility, with the break from November $1^{\text {st }}$ to mid-December used for maintenance works.

Treatment provided in the sanatorium consisted in "applying for the majority of the ill the rest in the open air, together with appropriate nutrition and pharmaceuticals in the form of medicines and injections. A lot of them, mainly children, were exposed to the light of quartz lamps if the exposure to sunlight was impossible ${ }^{\text {"12 }}$ Patients with advanced tuberculosis were not accepted by the facility. Sputum-positive patients, after the diagnosis being made during medical examination, were directed to P.D.Z. sanatoria in Zakopane or Otwock ${ }^{13}$.

The price for one day of stay in February and March as well as from September to December for those who held doctor's referral amounted to 2.25 zlotys and in 1935 it was reduced to 1.75 . Patients without such referral paid 4.0 zlotys and 3.5 zlotys respectively ${ }^{14}$.

\section{"Znicz" Railwayman Family Association's guesthouse in Tatarów}

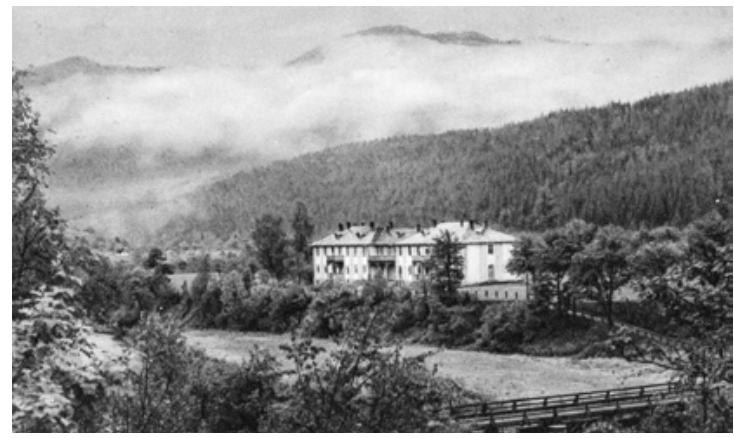

Fig. 6. Tatarów, "Znicz" Railwayman Family Association's guesthouse, 1930s Postcard from author's own collection.

Tatarów, Dom Rodzin Kolejowych „Znicz”, lata 30. XX. w. Karta pocztowa w zbiorach autora.

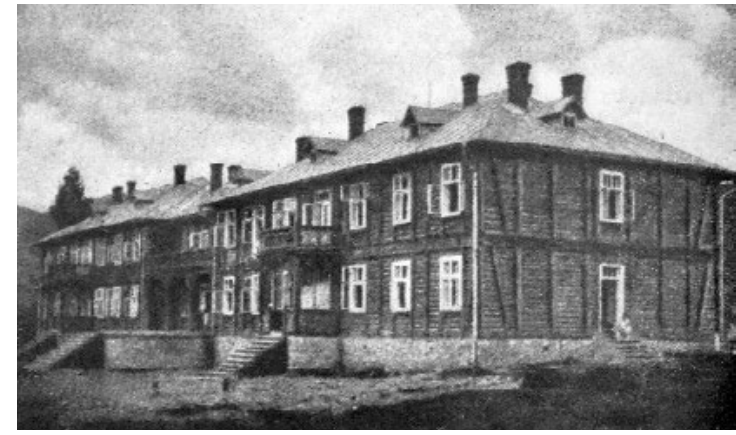

Fig. 7. Tatarów, "Znicz" Railwayman Family Association's guesthouse, 1930 [Tygodnik 1930].

Tatarów, Dom Rodzin Kolejowych „Znicz”, 1930 r. [Tygodnik 1930].

Exact date of the design and construction of "Znicz" Railwayman Family Association's guesthouse remains unknown. Designer's name was not discovered either. The building was for sure in operation in September $1930^{15}$. It was situated on the Prut River escarpment, at a small distance from the previously described policemen's sanatorium. It was a two-level building with a stone plinth with transom structure of timber walls (Photos 6-7). Straight cuboid construction narrowed in its central part, forming two broad side avant-corpses. It was covered with a hip roof including small dormers. Main entrance was located from the side of the river in the Western façade. It was accessible from a big terrace and emphasized with a porch portico. Additional entrances accentuated by porches with stone stairs leveling the plinth height were formed in the axis of the façade of side avant-corpses. The façades were plastered in white. The details of porches and balcony railings referred to regional motifs. The building was probably destroyed during the Second World War. A number of guesthouses and residential buildings were constructed in its place in the recent years.

\footnotetext{
12 Report from the activity of the Board of the P.D.Z. Association for the year 1935 [AAD-ZZS, sign. 115].

13 Ibidem.

14 Circular number 15. To the Delegates of the P.D.Z Association from the year 1935 [AAD-KGPP, sign. 2115].

15 Date on the archival photo from the farewell ball in 1930. Author's collections.
} 


\section{"Skarbówka" guesthouse in Worochta}

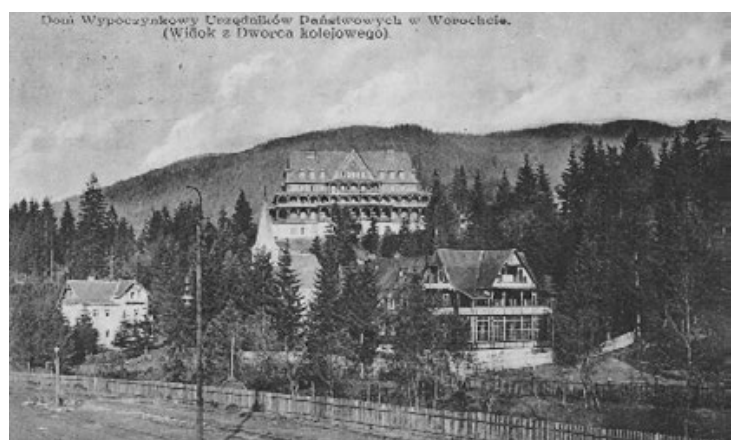

Fig. 8. Worochta, "Skarbówka" State Officials Society sanatorium, 1930s Postcard from author's own collection.

Worochta, sanatorium Towarzystwa Urzędników Państwowych "Skarbówka" lata 30. XX. w. Karta pocztowa w zbiorach autora.

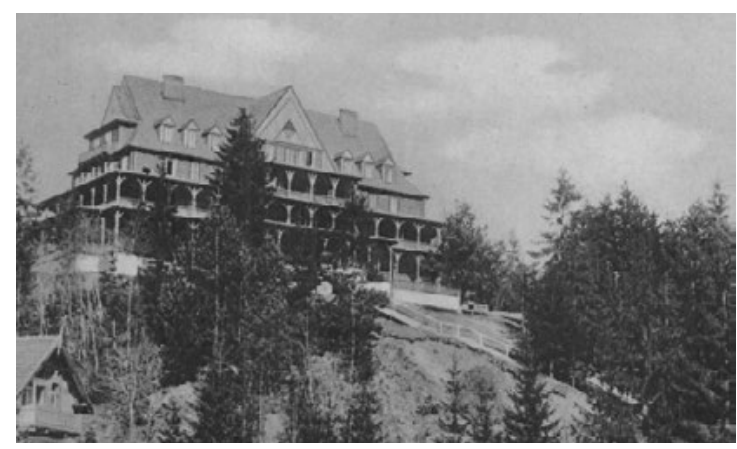

Fig. 9. Worochta, "Skarbówka" State Officials Society sanatorium, 1930s Postcard from author's own collection.

Worochta, sanatorium Towarzystwa Urzędników Państwowych „Skarbówka" lata 30. XX. w. Karta pocztowa w zbiorach autora.

On the hill, in the North-Eastern direction from the railway station in Worochta, a big sanatorium of the Association of State Officials with university degree was situated, including 60 rooms and called "Skarbówka" [Światowid 1929]. Architect Marian Aleksander Nikodemowicz from Lviv [PSB, 1978] was the designer of this timber object, visually dominating the center of the town. Its construction finished in 1929 [llustrowany 1929]. The plan was based on a rectangle, with the entrance within the Northern façade (Photo 8-9). This three-level object was covered by a steep roof with dormers and high mansards with pointed gables. The ground floor and first floor around the entire building were surrounded by porch galleries, supported on pillars with struts. The entrance axis was emphasized with front-end arcade portico within the ground floor and a porch within the third level. The curve of strut bends ensured semicircular shape of the arcades. Timber walls were left without plaster. The facility was bombed on June $23^{\text {rd }} 1941$ after the outbreak of the Soviet-German war [Petrowicz 1986], but it was finally destroyed after 1945 .

\section{"Gorgany" Health House in Jaremcze-Jamna}

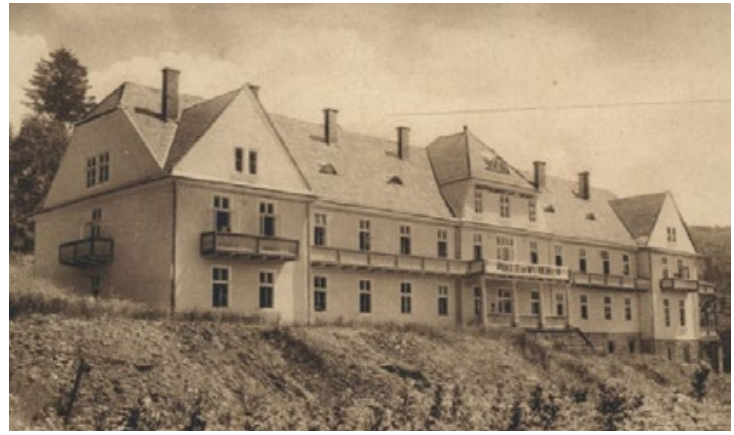

Fig. 10. Jaremcze-Jamna, "Gorgany" Health House of the Association of Tax Control Officials, 1930s Postcard from author's own collection.

Jaremcze-Jamna, Dom Zdrowia Stowarzyszenia Urzędników Kontroli Skarbowej "Gorgany", lata 30. XX w. Karta pocztowa w zbiorach autora.

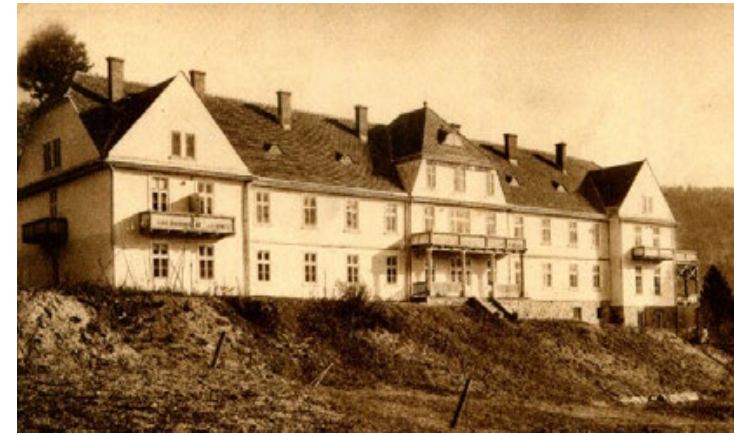

Fig. 11. Jaremcze-Jamna, "Gorgany" Health House of the Association of Tax Control Officials, 1930s after the reconstruction of front façade. Postcard from author's own collection. Jaremcze-Jamna, Dom Zdrowia Stowarzyszenia Urzędników Kontroli Skarbowej "Gorgany”, lata 30. XX w. po przebudowie elewacji frontowej. Karta pocztowa w zbiorach autora. 
"Gorgany" Health House of the Association of Tax Control Officials from Stanisławów was the full name of the facility. The construction finished probably in the early 1930s. It was a two-level building with a high and steep half-gable roof with dormers in the form of egg-and-darts (Photo 10). The building had plastered timber walls with a stone plinth. Its plan was based on an elongated rectangle. Interior arrangement was based on two and a half bays with internal corridor. Edge avant-corpses could be found in longer façades, finished with triangular gables. Main axis of the Southern façade was accentuated with a mansard, covered by the roof with sloping surface as well as entrance porch portico. First floor was emphasized with continuous horizontal balcony. This element was later deconstructed (Photo 11). The location of entrance stairs was also changed from the stairs adjacent to the façade to their axial arrangement.

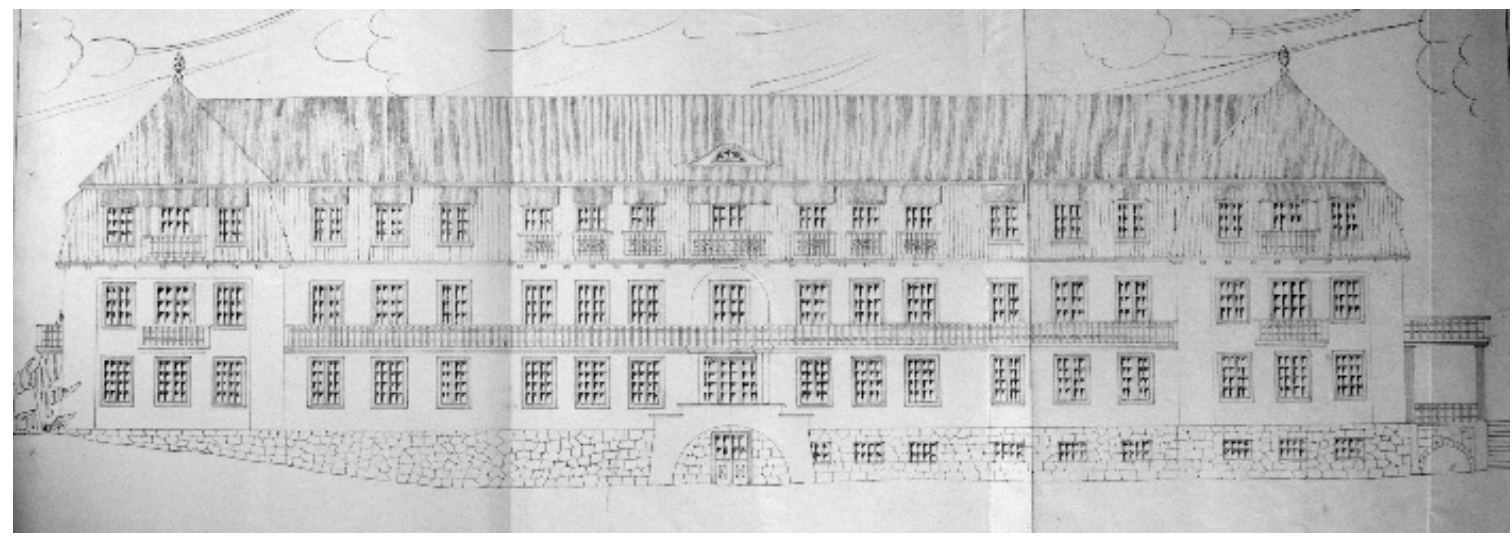

Fig. 12. Jaremcze-Jamna, "Gorgany" Health House of the Association of Tax Control Officials. Designer Eng. Maksymilian Platzer 1928, front façade [DAIFO, sign. 517].

Jaremcze-Jamna, Dom Zdrowia Stowarzyszenia Urzędników Kontroli Skarbowej "Gorgany”. Proj. inż. Maksymilian Platzer 1928, elewacja frontowa [DAIFO, sygn. 517].

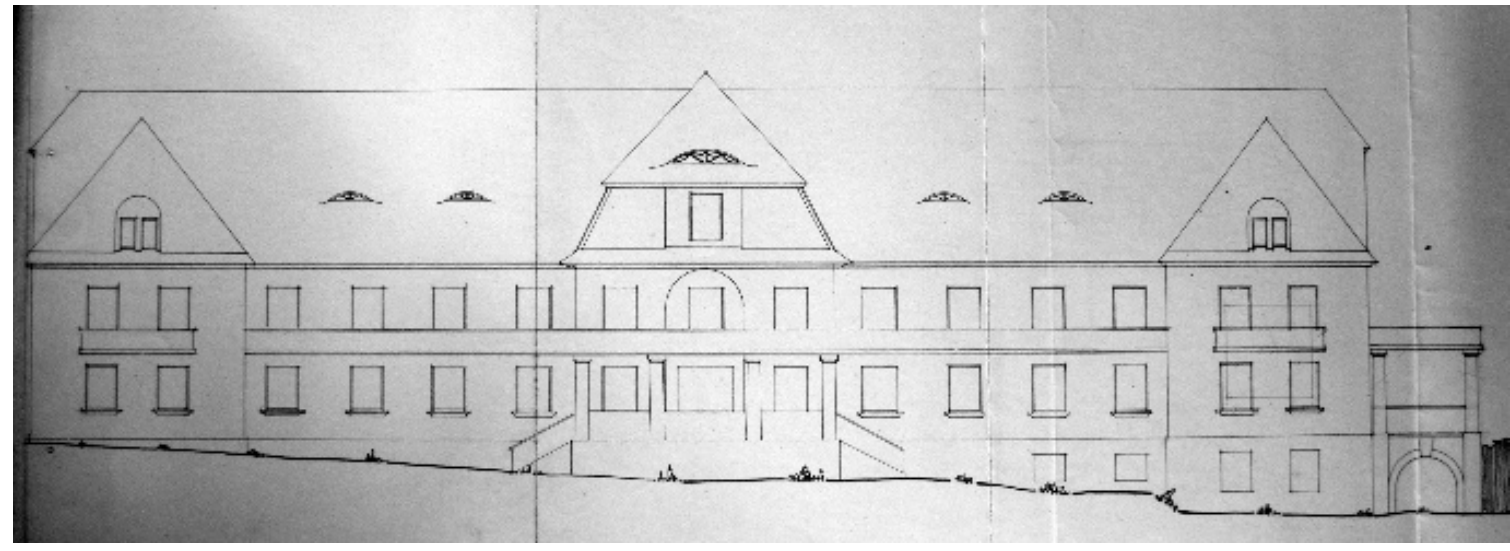

Fig. 13. Jaremcze-Jamna, "Gorgany" Health House of the Association of Tax Control Officials. Designer Eng. Julian Feuerman 1928, front façade [DAIFO, sign. 517].

Jaremcze-Jamna, Dom Zdrowia Stowarzyszenia Urzędników Kontroli Skarbowej „Gorgany”. Proj. inż. Julian Feuerman 1928, elewacja frontowa [DAIFO, sygn. 517].

The design of the facility was divided into two stages. The first concept, dated 1.03.1927, was performed by the engineer, government-authorized constructor Eng. Maksymilian Platzer from Stanisławów [DAIFO, sign. 517]. He suggested a two-level wooden building with mansard roof including rooms for guests (Photo 12). This concept was rejected by the Directorate of Public Works of the Voivodeship Office in Stanisławów in August 1928, with the justification that basing on the regulations in force: "the buildings which are not fireproof may not be higher than two levels (ground floor and the first floor) and it is forbidden to settle in the attics of 
such buildings. It is thus necessary to include the walls made of bricks or other fireproof material in the design, or to perform the design of a one-level timber building" [DAIFO, sign. 517]. As a result of ineffective attempts to convince the authority to change their decision, Engineer Julian Feuerman, also from Stanisławów, performed a new design in September 1928. This version, apart from slight modifications in the arrangement of plans and in the entrance zone, included the liquidation of usable mansard, replaced by non-habitable attic (Photo 13). The design, approved in 1929, was realized according to this concept. The date and circumstance of destruction of this object remain unknown.

\section{Health House of the Association of Ukrainian Teachers in Jaremcze-Jamna}

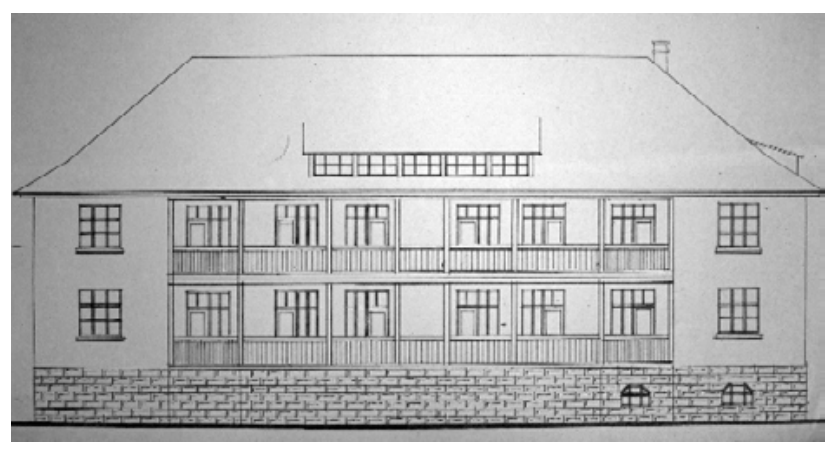

Fig. 14. Jaremcze-Jamna, Health House of the Association of Ukrainian Teachers. Designer Eng. Leon Borgenicht 1935, North-Eastern façade [DAIFO, sign. 2355].

Jaremcze-Jamna, Dom Zdrowia Uczytielskiej Hromady. Proj. inż. Leon Borgenicht 1935, elewacja płn.-wsch. [DAIFO, sygn. 2355].

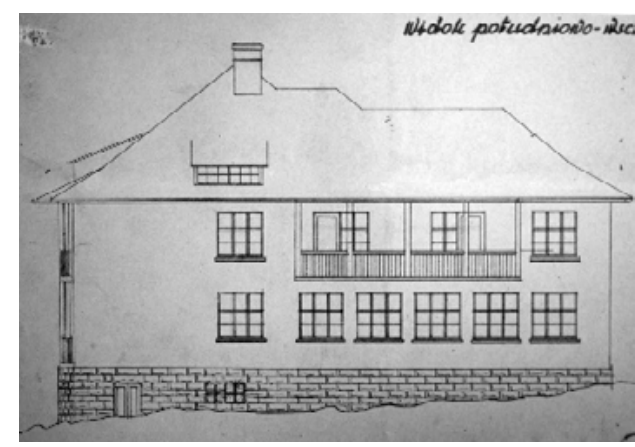

Fig. 15. Jaremcze-Jamna, Health House of the Association of Ukrainian Teachers. Designer Eng. Leon Borgenicht 1935, North-Western façade [DAIFO, sign. 2355].

Jaremcze-Jamna, Dom Zdrowia Uczytielskiej Hromady. Proj. inż. Leon Borgenicht 1935, elewacja płn.-zach. [DAIFO, sygn. 2355].

The existence of the facility, constructed for the Association of Ukrainian Teachers from Stanisławów, is known only thanks to the preserved architectural documentation from the year 1934, approved in April 1935 [DAIFO, sign. 2355 $]^{16}$. It was designed by government-authorized constructor and sworn court expert ${ }^{17}$, Engineer Leon Borgenicht from Nadwórna. The building, with cellars under its part and with plan based on the letter $L$, was covered by multi-slope roof with dormers (Photo 14-15). Its timber walls were plastered, had transom structure and were placed on the plinth performed from regular stone ashlars. In the central part of the South-Western façade, two-level deep loggia was designed. Its edge was slightly protruded to the front of the wall face. A smaller element of a similar character appeared on the first floor within the South-Eastern façade. At the same level, but within the North-Eastern façade, long veranda was designed, with roof supported on posts.

\section{Summary}

The presented buildings constitute formally diversified, but consistent facilities complex. They were distinguished by: their function connected with healthcare - health centers or sanatoria, similar capacity - they were designed for about 80 patients, the material from which they were constructed - timber transom structure as well as construction period - late 1920s and early 1930s.

The architecture of buildings, however, represents diversified formal stylistics. Tax Officials House and Policemen's Health Center followed the concept of Hutsul regionalism. The elements representing this trend 
(avant-corpses, entrance porticos, porches, balconies) were present in the Railway Sanatorium as well as the Health House of the Association of Tax Control Officials, even though their façades were characterized by great simplicity. The Health House of Ukrainian Teachers, in turn, represents the synthesis of regionalism and modernism. Simple and geometrized structure of the building was covered by a steep roof, while the façade was enriched with a long balcony and deep loggia.

\section{Literature and sources}

[1] Archiwum Akt Dawnych w Warszawie (Archives of Historical Records in Warsaw). Group: Main Police Headquarters in Warsaw [AAD-KGPP], different signatures.

[2] Archiwum Akt Dawnych w Warszawie (Archives of Historical Records in Warsaw). Group: Ministry of Treasury in Warsaw. Policemen's Health Center Association [AAD-MS], sign. 6432.

[3] Archiwum Akt Dawnych w Warszawie (Archives of Historical Records in Warsaw). Group: Collection of residual groups. Policemen's Health Center Association 1928-1939, [AAD-ZZS], different signatures.

[4] State Archives of the Ivano-Frankivsk Oblast in Ivano-Frankivsk, [DAIFO], different signatures.

[5] Czubiński J., 2008. Przykłady modernizmu w murowanej architekturze uzdrowiskowej miejscowości Worochta i Tatarów na Huculszczyźnie - zarys problematyki (Examples of modernism in brick spa architecture of the villages of Worochta and Tatarów in the Hutsul region - an outline), [in:] Teka Komisji Architektury, Urbanistyki i Studiów Krajobrazowych, PAN o. w Lublinie (Portfolio of the Commission of Architecture, Urban and Landscape Studies, Polish Academy of Sciences PAN Division in Lublin), Lublin, vol. IV A, 2008, p. 174-195.

[6] Journal of Laws of the Republic of Poland, 1922, No 31, item 254.

[7] Journal of Laws of the Republic of Poland, 1928 No 36, item 331.

[8] Gazeta Administracji i Policji Państwowej (Journal of State Administration and Police), 1924, no 28, (19) 587.

[9] Ilustrowany Kuryer Codzienny. Dodatek Ilustrowany (Illustrated Daily Courier. Illustrated Supplement), 1929 , no 46.

[10] Petrowicz T., 1986. Od Czarnohory do Białowieży (From Chornohora to Białowieża). WL, Lublin, p. 77.

[11] Polski Słownik Biograficzny (Polish Biographical Dictionary (PSB), 1978. Vol. XXIII, Ed. PAN, p. 123-124.

[12] Rocznik Policji Państwowej 1927 (State Police Annals 1927). Publishing house of the state police "Na posterunku" (On Post) journal.

[13] Policemen's Health Center Association 1924-1934, 1935. Warszawa.

[14] Światowid 1929, no 46/1929.

[15] Tygodnik Ilustrowany (Illustrated Weekly) 1930, no 39, p. 820-822.

\section{„Policyjny Dom Zdrowia” w Tatarowie jako przykład dużego budynku sanatoryjnego w dolinie Prutu na Huculszczyźnie}

\footnotetext{
Streszczenie: Artykuł prezentuje Sanatorium Policji Państwowej w Tatarowie w kontekście innych dużych obiektów o drewnianej konstrukcji powstałych około 1930 r. w dolinie Prutu na Huculszczyźnie. W tym czasie powstało tam kilka budynków mogących jednorazowo przyjąć ponad 80 kuracjuszy. W Tatarowie oddano do użytku dom wypoczynkowy "Znicz" Stowarzyszenia Rodziny Kolejowej. Towarzystwo Urzędników Skarbowych wybudowało dom wypoczynkowy "Skarbówka” w Worochcie. W Jaremczu - Jamna rozpoczął działalność Dom Zdrowia Stowarzyszenia Urzędników Kontroli Skarbowej Rzeczypospolitej Polskiej „Gorgany”. W połowie lat 30. zaprojektowano w tej samej miejscowości dom wypoczynkowy dla Stowarzyszenia Nauczycieli Ukraińskich.
}

Słowa kluczowe: architektura uzdrowiskowa, Huculszczyzna, Sanatorium Policji Państwowej, Tatarów 